\author{
Asian Journal of \\ Medical and Biological Research \\ ISSN 2411-4472 (Print) 2412-5571 (Online) \\ www.ebupress.com/journal/ajmbr
}

\title{
Article \\ Effect of dietary probiotics as antibiotic alternative on growth performance, organ development and meat quality in broiler chicken
}

\author{
Md. Sazedul Karim Sarker ${ }^{1}$, Md. Masud Rana ${ }^{2}$, Shabiha Sultana ${ }^{1}$, Noor Hossain ${ }^{3}$, Nathu Ram Sarker ${ }^{1}$ and \\ Talukder Nurun Nahar ${ }^{4}$ \\ ${ }^{1}$ Poultry Production Research Division, Bangladesh Livestock Research Institute, Savar, Dhaka 1341, \\ Bangladesh \\ ${ }^{2}$ Department of Animal Science, Chonbuk National University, Deokjin-gu, Jeonju, Jeollabuk-do, South Korea \\ ${ }^{3}$ Institute of Food Science and Technology, BCSIR, Dhaka-1205, Bangladesh \\ ${ }^{4}$ Director General, Bangladesh Livestock Research Institute, Savar, Dhaka 1341, Bangladesh
}

*Corresponding author: Dr. Md. Sazedul Karim Sarker, Senior Scientific Officer, Poultry Production Research Division, Bangladesh Livestock Research Institute, Savar, Dhaka 1341, Bangladesh. E-mail: sazdulkarim@yahoo.com

Received: 07 June 2017/Accepted: 20 June 2017/ Published: 29 June 2017

\begin{abstract}
The aim of the study was to evaluate the effect of dietary probiotics on broiler growth performance, organ development and meat quality in replacing oxytetracycline. Dietary treatments were control (basal diet without additives), antibiotic (basal diet with $0.05 \%$ oxytetracycline), basal diet with Bacillus subtilis and basal diet with Lactobacillus spp. A total of 192 birds were randomly allotted to four dietary treatments with four replicates having 12 birds each. Feed and water were supplied ad libitum. The results of the current study revealed that growth performances of broiler did not show significant difference $(\mathrm{P}>0.05)$ among the treatments. Body weight and weight gain were numerically higher and FCR was numerically lower in broilers fed a diet containing 2 different single strains of probiotic than control. Though there were no treatment effects $(\mathrm{P}>0.05)$ on the weights of the liver, heart, kidney, spleen, gizzard, intestine and dressing percentage, but abdominal fat content was found significantly higher $(\mathrm{P}<0.05)$ in antibiotic treated group than that of single strain probiotic (Lactobacillus spp.) feeding group. Significant differences were also observed in meat color values where antibiotic fed broiler meat showed higher redness, lower lightness and yellowness and birds fed the control feed had higher lightness and yellowness of meat than probiotic fed chicken. TBA, $\mathrm{P}^{\mathrm{H}}$ and cooking loss were not affected by the treatments. Therefore, we concluded that use of selected probiotics resulted in improved performance parameters and reduced abdominal fat pad in broiler chickens. Moreover, addition of the probiotics in broiler diet for replacing antibiotic could be utilized for safe poultry meat production.
\end{abstract}

Keywords: probiotics; oxytetracycline (OTC); broiler chicks; growth performance; thiobarbituric acid value (TBA)

\footnotetext{
1. Introduction

Oxytetracycline (OTC) is a broad spectrum antibiotic known as tetracyclines which were developed to enhance the control of bacterial infections (Alam, 2000). According to Zulkifli et al. (2000); chicks given diet supplemented with $50 \mathrm{mg} / \mathrm{kg}$ OTC during 21-42days of age increased body weight gain (BWG) but the antibody produced against New castle disease virus (NDV) was not affected. But feeding of antibiotics is risky (Casewell et al., 2003) not only due to crossresistance but also due to multiple resistances. This could pose a threat to public health if dangerous infections of drug-resistant bacteria were spread via the food chain (Smith et al., 2003). As a result, the use of antibiotics as growth promoters was banned from the EU on January 1, 2006 (Burch, 2006) and the potential for a ban in the United States and some other countries in Asia. In Bangladesh
} 
the use of most antibiotics growth promoter (AGP) also has been banned to preserve the effectiveness of important human drugs (Casewell et al., 2003). So, there is increasing interest in finding alternatives to antibiotics for poultryproduction. The focus of alternative strategies has been to prevent proliferation of pathogenic bacteria and modulation of indigenous bacteria so that the health, immune status and performance are improved (Ravindran, 2006). Lactobacillus, Bacillus and Saccharomyces cerevisiae (SC), as a Direct-fed microbials (DFM), have been studied as potential as alternatives approach to feed additives (Salim et al., 2013). Feeding probiotics helps to maintain a beneficial intestinal microflora, enhances the host's resistance to enteric pathogens such as Salmonella and Campylobacter species, and results in a healthy gastrointestinal environment with an improved intestinal function, feed conversion, weight gain and performance of birds (Dalloul et al., 2003; Vila et al., 2009; Mountzoris et al., 2010).

As probiotics are live cultures of harmless bacteria or yeast species that equilibrate intestinal microflora to benefit the host (Ferencik et al., 2000; Chen et al., 2013), which have been demonstrated to be helpful in maintaining the intestinal ecosystem and enhancing animal health, therefore, a lot of researcher focused on it and used single or double or mixed stain.

Among a number of bacterial species used as probiotics, spore-forming Bacillus spp. has been identified as a suitable probiotic because of the resistance of its spores to harsh conditions and long-term storage at ambient temperature (Sinol et al., 2012; Chen et al., 2013). Lactobacilli are normal components of the healthy intestinal microflora. However, in our country context which are convenient and to the best of our knowledge, the effects of Bacillus subtilis and Lactobacillus acidophilus endospores in broiler chickens have not been investigated in detail. These factors may be critical in the Bangladesh, where most of the farmers have been used antibiotics into their poultry feed to enhance birds performance and disease resistant capacity. Therefore, poultry feed industry needs adequate information on this aspect to augment commercial broiler production in Bangladesh. Furthermore, there is a way to increase the use of probiotics in diets for animals, which is a more reasonable option, since they do not leave residues in the environment, in the animal body and do not cause cross-resistance in men compared with antibiotics (Nepomuceno and Andreatti, 2000). In this context, this study was designed to assess the effect of Bacillus subtilis and Lactobacillus spp. endospores on growth performance, relative organ weight and meat qualityin broiler chickens.

\section{Materials and Methods}

\subsection{Birds and housing}

A total of one hundred ninety two 1-d-old mix sexed Cobb broilers were obtained from a local commercial hatchery. Broilers were randomly allocated in 4 experimental treatments for 5 wk. Each treatment had 48 broilers arranged in 4 replicates of 12 broilers each. Each replicate was assigned to a clean floor pen $\left(2 \mathrm{~m}^{2}\right)$ and birds were raised on a rice straw based litter. Heat was provided with a heating lamp per pen. The ambient temperature in experimental house was maintained at $32^{\circ} \mathrm{C}$ during the first week and thereafter decreased by $3^{\circ} \mathrm{C}$ in the third week, and finally fixed at $22^{\circ} \mathrm{C}$ up to end of the experiment. The experiment was lasted for 35 day.

\subsection{Dietary treatments}

To meet the nutrient requirements of the broiler chicken over this period, a complete basal diet was formulated for each of the 2 stages of growth; starter and finisher. The diets were formulated to meet the nutrients requirements of broilers as recommended by the National Research Council (NRC, 1994). The experimental treatments received a 1) Control, 2) Antibiotic (added with OTC), 3) Basal diet with probiotic Bacillus subtilis, and 4) Basal diet with Lactobacillus spp. The probiotics were prepared according to manufacturer instruction. The basal diet was formulated for starter ( 1 to $21 \mathrm{~d}$ ) and finisher ( 22 to $35 \mathrm{~d}$ ) of broiler growth periods and its composition is shown in Table 1. The basal diet was prepared in each week and stored in sacks and was kept in a cool place. Experimental diets and water were provided ad libitum.

\subsection{Growth performance traits}

Growth performance parameters such as body weight (BW), weight gain (WG), feed intake (FI), and feed conversion ratio (FCR), were determined in each week. During starter (0-3 wks) and finisher (4-5wks) period body weight $(\mathrm{BW})$, weight gain $(\mathrm{WG})$, feed intake $(\mathrm{FI})$, and feed conversion ratio (FCR) were calculated for the whole duration of the experiment. 


\subsection{Organ weights and carcass yield percentages}

At the end of experiment, after weighing, 4 birds per treatment were randomly selected and killed humanly by cervical dislocation. The liver, heart, kidney, spleen gizzard, abdominal fat and intestine were excised and weighed. Afterward, the birds were scalded, de-feathered, and carcasses were eviscerated. The head and feet were removed, and calculated as a percentage of live body weight and also carefully examined to detect any pathological lesion or damages. The weight of intestine was also measured and recorded.

\subsection{Meat characteristics}

Muscular $\mathrm{pH}$ values were determined on Pectorals major muscle with a needle probe $24 \mathrm{~h}$ post mortem with Mettler MP 120-B digital $\mathrm{pH}$-meter. All pH measurements were conducted on the anterior end of the right breast. The $\mathrm{pH}$ meter was standardized by a two-point method against standard buffers of $\mathrm{pH} 4.0$ and $\mathrm{pH}$ 7.0.

Cooking loss was calculated as [sample weight before cooking minus sample weight after cooking] $\times 100 /$ sample weight before cooking.

The colour of breast meat was determined after $24 \mathrm{~h}$ of cooling the carcass with Minolta CR-300 colorimeter (MINOLTA CAMERA Co. Ltd., Osaka, Japan) calibrated against white plate (CIE L* - lightness, a* - redness, $\mathrm{b}^{*}$ - yellowness) with $8 \mathrm{~mm}$ optical probe diameter, D65 illuminant and $2^{\circ}$ observer. The meat colour is presented as CIE-L*a*b* (Commission Internationale de l'Eclairage, 1976).

Meat samples (5 g) from each breast cut were used for the analysis of the thiobarbituric acid reactive substances (TBA) by using the aqueous acid extraction method of Pikul et al., 1989; Gomes et al., 2003 to determine lipid oxidation. The reaction produces a red color which can be measured using a spectrophotometer.

\subsection{Statistical analysis}

All data were subjected to analysis of variance procedures appropriate for a completely randomized design using the general linear model procedures of SAS (SAS Inst. Inc., Cary, NC 2005). The mean differences among different treatments were separated by Duncan's multiple range tests. A level of $(\mathrm{P}<0.05)$ was used as the criterion for statistical significance.

\section{Results and Discussion}

\subsection{Growth Performance Traits}

The effects of dietary antibiotic, Bacillus spp. and Labacillus spp. supplementation on the growth performance of broilers at $0-5$ weeks are shown in Table 2. From day old to $5^{\text {th }}$ weeks of age, there were no significant differences in BW, WG, FI or FCR among all treatment groups $(P>0.05)$.It was indicated that dietary inclusion of probiotic and antibiotic supported a superior performance of chicks than control in broilers diet. However, several investigators Bafundo et al. (2003), Ferket (2004), and Lindsey (1985) reviewed the various benefits of feeding antibiotic growth promoters which may control and limit the growth and colonization of a variety of pathogenic and nonpathogenic species of bacteria in chicks gut. According to Ramarao et al. (2004) it was also not possible to observe any influence of probiotics on broiler weight gain, as opposed to Kabir et al. (2004), who obtained higher weight gain in broilers fed aprobiotic product. Our results also did not find any differences among allgroups but numerically higher than control. The parameter feed conversion ratio was not statistically different between treatments in $0-5$ weeks in this experiment. Our results were similar to Loddi $e t$ al. (2000), who worked with a probiotic product containing Enterococcus faecium $(1 \times 1010 \mathrm{CFU} / \mathrm{g}$ product), where we found numerically lower FCR in Lactobacillus administration group and higher in control group. So, it can be said that probiotic can be substitute for antibiotic. European Poultry Efficiency Factor (EPEF) was calculated where the greater efficiency in treatment $\mathrm{T}_{3}$ and lower efficiency in control based on mortality $(2.08 \%$ for all treatments), weight gain and feed conversion ratio.

\subsection{Absolute organ weights and carcass yield percentages}

The organ weight like liver, heart, kidney, spleen, gizzard and intestine did not influenced by the treatments but abdominal fat was showed significant difference among the treatments. Moreover, antibiotic containing diet found a higher relative abdominal fat and broilers fed lactobacillus diets showed lower fat weight compared with other treatments $(P<0.05)$.

Fat deposition in the abdominal area of broilers is regarded as waste in the poultry industry; since it represents a loss in the market and consumer acceptability, and enhances expense during the treatment of effluent produced when processing broilers. The obtained results of this study indicate that probiotic supplementation of broilers diet has the potential to lessen this type of waste by reduction of the fat content in the abdominal area of birds. In accord to our results, Mohamed et al. (2008) reported that the highest abdominal fat percentage value was 
recorded for birds fed the control diet (2.21\%) while the lowest value was recorded for birds fed the MOS supplemented diet (1.78\%). Similarly, they did not notice any significant impact of supplements on dressing percentage, liver, heart, and gizzard relative weight. Our findings were almost similar to Mohamed et al. (2008) but higher abdominal fat was found to antibiotic group may be due to the higher feed intake in this group.

Though dressing \% was not different significantly but numerically higher number was observed in Bacillus containing feed than other treatments. Boratto et al. (2004) found carcass yield percentages were higher for the no probiotic-fed female broilers than for the control. This point was opposite to our results.

Table 1. Composition of basal diet.

\begin{tabular}{lll}
\hline Item & Starter (1-21d) & Finisher (22-35 d) \\
\hline Ingredient (\%) & & \\
Maize & 52 & 60 \\
Protein concentrate & 6 & 7.4 \\
Rice polish & 4.6 & 3 \\
Soybean & 33.3 & 25.6 \\
Di calcium phosphate & 1 & 1 \\
Vitamin-mineral premix & 0.25 & 0.25 \\
Salt & 0.5 & 0.5 \\
Oil & 1.9 & 2 \\
Lysine & 0.1 & 0.1 \\
Methionine & 0.1 & 0.1 \\
Limestone & 0.5 & 0.3 \\
\hline Calculated analysis (per kg of diet) & & \\
\hline Moisture (\%) & 10.64 & 13.47 \\
Ash & 7.16 & 6.06 \\
CP & 22.69 & 19.49 \\
Fat & 3.44 & 4.22 \\
Fiber & 4.31 & 4.62 \\
\hline
\end{tabular}

Table 2. Performance (0-5 wks) of broiler chicken with addition of antibiotic and probiotics in broiler diet.

\begin{tabular}{llllll}
\hline Tr. & BW & WG & FI & FCR & EPEF \\
\hline $\mathrm{T}_{0}$ & 1818.54 & 1773.54 & 3259.27 & 1.84 & 276.50 \\
$\mathrm{~T}_{1}$ & 1853.81 & 1808.81 & 3291.42 & 1.82 & 284.96 \\
$\mathrm{~T}_{2}$ & 1836.08 & 1791.08 & 3267.81 & 1.83 & 280.70 \\
$\mathrm{~T}_{3}$ & 1831.75 & 1786.75 & 3231.19 & 1.81 & 289.14 \\
$\mathrm{SEM}$ & 18.789 & 18.789 & 15.232 & 0.015 & - \\
$\mathrm{P}-$ Value & 0.944 & 0.944 & 0.618 & 0.945 & - \\
\hline
\end{tabular}

$\mathrm{T}_{0}=$ Control $\mathrm{T}_{1}=\mathrm{OTC}, \mathrm{T}_{2}=$ Probiotic $($ Bacillus $), \mathrm{T}_{3}=$ Probiotic $($ Lactobacillus $) ;$ *EPEF = European Poultry Efficiency Factor (Average gram gained/day $\times \%$ Survival rate $/ \mathrm{FCR} \times 10$ ).

Table 3. Effects of dietary treatments on absolute organ weights of broiler chickens (g).

\begin{tabular}{lllllllll}
\hline Tr. & Liver & Heart & Kidney & Spleen & Gizzard & Abdominal fat & Intestine & Dressing \% \\
\hline $\mathrm{T}_{0}$ & 42.00 & 11.75 & 4.75 & 2.75 & 56.25 & $19.50^{\mathrm{ab}}$ & 144.75 & 71.57 \\
$\mathrm{~T}_{1}$ & 42.25 & 20.50 & 4.25 & 2.50 & 53.25 & $23.75^{\mathrm{a}}$ & 144.25 & 71.84 \\
$\mathrm{~T}_{2}$ & 40.50 & 11.75 & 4.75 & 2.75 & 52.50 & $17.25^{\mathrm{b}}$ & 140.00 & 72.40 \\
$\mathrm{~T}_{3}$ & 43.25 & 11.75 & 5.25 & 3.25 & 56.75 & $15.75^{\mathrm{b}}$ & 157.25 & 71.34 \\
$\mathrm{SEM}$ & 0.917 & 2.229 & 0.322 & 0.163 & 0.907 & 0.997 & 2.601 & 0.316 \\
$\mathrm{P}-$ Value & 0.802 & 0.445 & 0.791 & 0.467 & 0.261 & 0.0084 & 0.087 & 0.718 \\
\hline
\end{tabular}

$\mathrm{T}_{0}=$ Control $\mathrm{T}_{1=}$ antibiotic, $\mathrm{T}_{2}$ = Probiotic(Bacillus $), \mathrm{T}_{3}$ = Probiotic $($ Lactobacillus $)$ 
Table 4. Different meat quality characteristics of broiler feeding with different feed additives.

\begin{tabular}{lllllll}
\hline Treatment & TBA & $\mathbf{P}^{\mathbf{H}}$ & Cooking loss & \multicolumn{3}{c}{ Color values } \\
\cline { 6 - 7 } & & & & $\mathbf{L}^{*}$ & $\mathbf{a}^{*}$ & $\mathbf{b}^{*}$ \\
\hline $\mathrm{T}_{0}$ & 8.81 & 6.30 & 18.25 & $53.33^{\mathrm{a}}$ & $4.44^{\mathrm{bc}}$ & 9.01 \\
$\mathrm{~T}_{1}$ & 10.8 & 6.36 & 15.04 & $49.11^{\mathrm{b}}$ & $6.41^{\mathrm{a}}$ & 7.23 \\
$\mathrm{~T}_{2}$ & 8.63 & 6.23 & 18.36 & $51.23^{\mathrm{ab}}$ & $3.48^{\mathrm{c}}$ & 8.21 \\
$\mathrm{~T}_{3}$ & 11.19 & 6.42 & 17.76 & $51.99^{\mathrm{a}}$ & $5.31^{\mathrm{ab}}$ & 8.67 \\
$\mathrm{SEM}$ & 0.693 & 0.043 & 0.606 & 0.526 & 0.399 & 0.385 \\
P-Value & 0.472 & 0.498 & 0.169 & 0.016 & 0.038 & 0.42 \\
\hline
\end{tabular}

* Meat color values of lightness $\left(\mathrm{L}^{*}\right)$, redness $\left(\mathrm{a}^{*}\right)$, and yellowness $(\mathrm{b} *)$

\subsection{Meat quality characteristics}

Meat colors were significantly influenced by the treatments where antibiotic containing feed showed higher redness and lower lightness and yellowness and birds fed the control feed had higher lightness and yellowness of meat.

Color is one of the main indicators of the quality of most foods. $\mathrm{L}^{*}$ value is the main parameter that determines poultry meat color. According to Contreras and Beraquet (1995), values of $L^{*}$ from 46.4 to 49.7 for the breast color are normal. Our result was similar to antibiotic containing group may be due to $\mathrm{pH}$ increased the $\mathrm{L}^{*}$ value decreased, i.e. while darkness of meat increased the lightness declined (Allen et al., 1997; Fletcher et al., 2000). According to Karaoğlu, 2005; the birds fed with level of $0.1 \%$ probiotic (P1) also had the lowest a* value among treatment groups $(\mathrm{p}<0.05)$. In our experiment, Bacillus administration group $\left(\mathrm{T}_{2}\right)$ showed the similar results. $\mathrm{a}^{*}$ value indicating redness in skin may be due to slaughter age of the bird, because, as many researchers stated the age has reportedly influenced the myoglobin content of other species (American Meat Institute Foundation, 1960). Results of our experiment show clearly that the use of the probiotic in broiler diets prevented the increase of $a^{*}$ value indicating redness. In this experiment, $b^{*}$ value was higher in control group may be due to the moisture loss of skin, and depending on this the carcasses darkened with increased $b^{*}$ value after slaughtering $(\mathrm{p}<0.05)$. There were no statistically significant differences $(\mathrm{p}>0.05)$ found in TBA, $\mathrm{P}^{\mathrm{H}}$ and cooking loss by the treatments.

In probiotic, $\mathrm{pH}$ value was slightly numerically lower than control. According to (Komiyama, 2006; Ludtke, 2009), due to the rapid metabolic transformation of glycogen into lactic acid, which results in achieving ultimate $\mathrm{pH}$ before carcass cools, causing protein denaturation, and consequently, meat becomes pale, soft and exudative. According to (Gheisari, 2011) the extent of oxidative rancidity in a fat may also be determined by its TBA number. The 2- thiobarbituric acid (TBA) test is believed to measure the breakdown products of unsaturated fatty acid oxidation. Typically, the TBA number of a sample shows a steady increase as it becomes more rancid, but a certain amount of variation is found between the TBA numbers obtained for similar fresh samples. In this study the Bacillus containing diet showed numerically decreased number of TBA value than other treatments.

\section{Conclusions}

In conclusion, the use of probiotics and antibiotics in feed for broiler chickens does not statistically affect the performance of broiler in our study. However, probiotic fed chickens had higher body weight, dressing percentage and higher European Broiler Index and at the same time lowered abdominal fat and cooking losses. Therefore, probiotics product could be a potential alternative to antibiotic growth promoters (e.g. Oxitetracycline) in broiler diets. So, further follow-up study is necessary to determine probiotics inoculation levels in the broiler diet and in replacing antibiotic in broiler feed.

\section{Conflict of interest}

None to declare.

\section{References}

Alam S, 2000. Handbook of poultry disease andtreatment. 9th Ed. Anglo Egyptian Library Press, Egypt in Arabic.28, 34-40.

Allen PC, JLydon and H Danforth, 1997.Effects of components of Artemisia annuaoncoccidia infections in chickens.Poult. Sci., 76: 1156-1163.

American Meat Institute Foundation. 1960. The Science of Meat and Meat Products. W.H. Freman and Co., San Francisco,California. USA. 
Bafundo, KW, LA Cox and R Bywater, 2003. Review lends perspective to recent scientific findings onvirginiamycin, antibiotic resistance debate. Feedstuffs, 75: 26-27.

Boratto, AJ, 2004.Uso de antibiótico, de probiótico e de homeopatia, inoculadosounão com Escherichia coli, parafrangos de cortecriadosemconforto. Revist. Brasil. de Zootec., 33: 1477-1485.

Burch D. 2006. Anticipated effects of the withdrawal of antibiotic growthpromoters (AGPs) from pigs in the

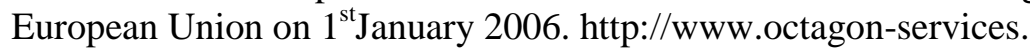

Casewell M, C Friis, E Marco, P McMullin and I Phillips, 2003. The European ban on growthpromotingantibiotics and emerging consequences for human andanimal health. The J. of Antimicrob. Chemother., 52: 159-161.

Chen W, JP Wang, L Yan and YQ Huang, 2013. Evaluation of probiotics in diets with different nutrient densities on growth performance, blood characteristics, relative organ weight and breast meat characteristics in broilers. Bri. Poult. Sci., 54: 635-641.

Contreras CJC and NJ Beraquet, 1995. Effect of deboning and electrical stimulation on post mortem biochemical changes in chicken breast P. major. In:International Congress of Meat Science and Technology, 41th The Hague, Netherlands. 4: 46. 41.

Dalloul RA, HS Lillehoj, TA Shellem and JA Doerr, 2003. Enhanced mucosal immunity against Eimeria acervulina in broilers fed a Lactobacillus-based probiotic. Poult. Sci., 82: 62-66.

Ferket PR, 2004. Alternatives to antibiotics in poultry production: responses, practical experience and recommendations. Nutritional biotechnology in the feed and food industries: Proceedings of Alltech's $20^{\text {th }}$ Annual Symposium, Kentucky, USA, 56-67.

Fletcher DL, M Qiao and DP Smith, 2000.The relationship of raw broiler breast meat colour and pH to cooked meat colour and $\mathrm{pH}$. Poult. Sci., 79: 784-788.

Gheisari HR, 2011. Correlation between acid, TBA, peroxide and iodine values, catalase and glutathione peroxidase activities of chicken, cattle and camel meat during refrigerated storage. Vet. World, 4: 153-157.

Kabir SML, MM Rahman, MB Rahman, MM Rahman and SU Ahmed, 2004. The dynamics of probiotics on growth performance and immune response in broilers. Int. J. Poult. Sci., 3: 361-364.

Komiyama CM, 2006. Caracterização e ocorrência de carne pálidaemfrangos de corte e seuefeitonaelaboração de produtosindustrializados [dissertação].Botucatu(SP): Faculdade de MedicinaVeterinária e Zootecnia, UniversidadeEstadualPaulista.

Lindsey TO, 1985. Virginiamycin: Unique control of gut microbial metabolism enhances nutrient availability. Pages 41-59 in Proc. Pacesetter Conference Stafac (virginiamycin) for Broilers. Smith Kline Animal Health Products, West Chester, PA.

Loddi MM, 2000. Uso de probiótico e antibióticosobre o desempenho, o rendimento e a qualidade de carcaça de frangos de corte. Revis. Brasil. de Zootec., 29: 1124-1131.

Ludtke CH, CEW Nogueira, W Bertoloni, OA Dalla Costa and GJD Soares, 2009. Bem-estar animal no transporte de suínos e suainfluêncianaqualidade da carne e nosparâmetrosfisiológicos do estresse [comunicadoTécnico 475]. Concórdia: EMBRAPA Suínos e Aves.

Mohamed MA, HMA Hassan and EMAEl-Barkouky, 2008. Effect of mannan oligosaccharide on performance and carcass characteristics of broiler chicks. J. Agric. and Soc. Sci., 4: 7-13.

Mountzouris KC, P Tsitrsikos, I Palamidi, A Arvaniti, M Mohnl, G Schatzmayr and K Fegeros, 2010. Effect of probiotic inclusion levels in broiler nutrition on growth performance, nutrient digestibility, plasma immunoglobulins, and cecal microflora composition. Poult. Sci., 89: 58-67.

Nepomuceno ES and RLF Andreatti, 2000. Probióticos e prebióticosnaavicultura. In: Simpósio DE SanidadeAvícola, 2,Santa Maria. Anais... Concórdia: EmbrapaSuínos e Aves, 1: 45-55.

Pikul J, DE Leszczynski and FA Kummerow, 1989. Evaluation of three modified TBA methods for measuring lipid oxidation in chicken meat. J. of Agric. and Food Chem., 37: 1309-1313.

Ramarao SV, MR Reddy and MVLN Raju, 2004. Growth, nutrient utilization competence in broiler chicken fed probiotic, gut acidifier and antibacterial compounds. Ind. J. Poult. Sci., 39: 125-130.

RavindranV, 2006. Broiler nutrition in New Zealand - Challenges and Strategies.Accessed in.www.feedinfo.com.

SalimHM, HK Kang, N Akter, DW Kim, JH Kim, MJ Kim, JC Na, HB Jong, HC Choi, OS Suh and KW Kim, 2013. Supplementation of direct-fed microbials as an alternative to antibiotic on growth performance, immune response, cecal microbial population, and ileal morphology of broiler chickens. Poult. Sci., 92: 2084-2090. 
Sinol S, SL Ingale, YW Kim, JS Kim, KH Kima, JD Lohakarea, EK Kim, HS Kim, MH Ryu, IK Kwon and BJ Chae, 2012. Effect of supplementation of Bacillus subtilis LS 1-2 to broiler diets on growth performance, nutrient retention, caecal microbiology and small intestinal morphology. Res. Vet. Sci., 93: 264-268.

Smith DL, JA Johnson, AD Hrris and JP Furuno, EN Perencevich and JGJ Morris, 2003. Assessing risks for a pre-emergent pathogen: virginiamycin use and the emergence of streptogramin resistance in Enterococcus faecium. Lanc. Infect. Dis., 3: 241-249.

Vila B, A Fontgibell, I Badiola, E Esteve-Garcia, G Jiménez, M Castillo and J Brufau, 2009. Reduction of Salmonella enterica var. Enteritidis colonization and invasion by Bacillus cereus var. toyoi inclusion in poultry feeds. Poult. Sci., 88: 975-979.

Zulkifli I, N Abdullah, NM Azrin and YW Ho, 2000. Growth performance and immune response of two commercial broiler strains fed diet containing Lactobacillus cultures and oxytetracycline under heat stress condition. J. Bri. Poult. Sci. 41: 593-597. 